\title{
LITHOSPHERIC MANTLE IN EASTERN FINLAND: A 250 KM 3D TRANSECT
}

\author{
Hugh O'Brien', Marja Lehtonen ${ }^{1}$, Roy Spencer ${ }^{2}$ and Andrew Birnie ${ }^{2}$ \\ ${ }^{I}$ Geological Survey of Finland, Espoo, Finland; ${ }^{2}$ European Diamonds PLC, London, U.K.
}

\section{ABSTRACT}

Two kimberlite provinces $250 \mathrm{~km}$ apart in Eastern Finland within the Karelian craton have produced mantle-derived xenoliths and xenocrysts that record striking differences in the lithospheric mantle in these two areas. To the SW occur the $600 \mathrm{Ma}$ old Group I kimberlites from the Kaavi-Kuopio region of CentralEastern Finland. To the NE are rocks intermediate to olivine lamproite and Group II kimberlite located in the area of Kuhmo. Chrome diopside thermobarometry from Kaavi-Kuopio fits very well with a $36 \mathrm{~mW} / \mathrm{m} 2$ geotherm calculated based on heat flow constraints and P-T data derived from xenoliths. Preliminary chrome diopside data from Kuhmo indicate a similar geotherm, although the present sparse dataset is limited to low temperatures. Xenocrystic pyrope major and trace element compositions reveal three distinct layers in the lithospheric mantle at the SW edge of the craton: 1. A significant low temperature (700-850 degrees) Ca-rich but $\mathrm{Ti}, \mathrm{Y}$ and $\mathrm{Zr}$ depleted "wehrlitic" pyrope-bearing mantle 2. A variably depleted lherzolite (G9) and harzburgite (G10) bearing horizon from 900-1200 degrees, or 150 to $185 \mathrm{~km}$. 3. A fertile deep layer from 180 to $250 \mathrm{~km}$ possibly representing Proterozoic underplating or a melt-enriched version of layer 2. In contrast, xenocrystic pyrope data from the Kuhmo area show this lithospheric mantle to be rather more simple, with a variably depleted lherzolite (G9) and harzburgite (G10) bearing horizon extending from the very top of the garnet bearing mantle at about $80 \mathrm{~km}$ depth, to a depth of $260 \mathrm{~km}$. Present data appear to show a meltmetasomatized layer of about $30 \mathrm{~km}$ thickness at the very base of the Kuhmo mantle lithosphere, possibly corresponding to layer 3 at Kaavi-Kuopio. The more complicated mantle stratigraphy at Kaavi-Kuopio is explained by its location at the margin of the craton, where significant shortening and overthrusting in the crust occurred from 1.9 to $1.8 \mathrm{Ga}$. The mantle underlying the Kuhmo area apparently suffered less reactivation during this major collisional event and likely represents an older nucleus of the Karelian craton. Correspondingly, diamond prospective zones in these two areas are significantly different, with about 40 vertical $\mathrm{km}$ at Kaavi-Kuopio as opposed to about 110 vertical $\mathrm{km}$ of prospective peridotites at Kuhmo.

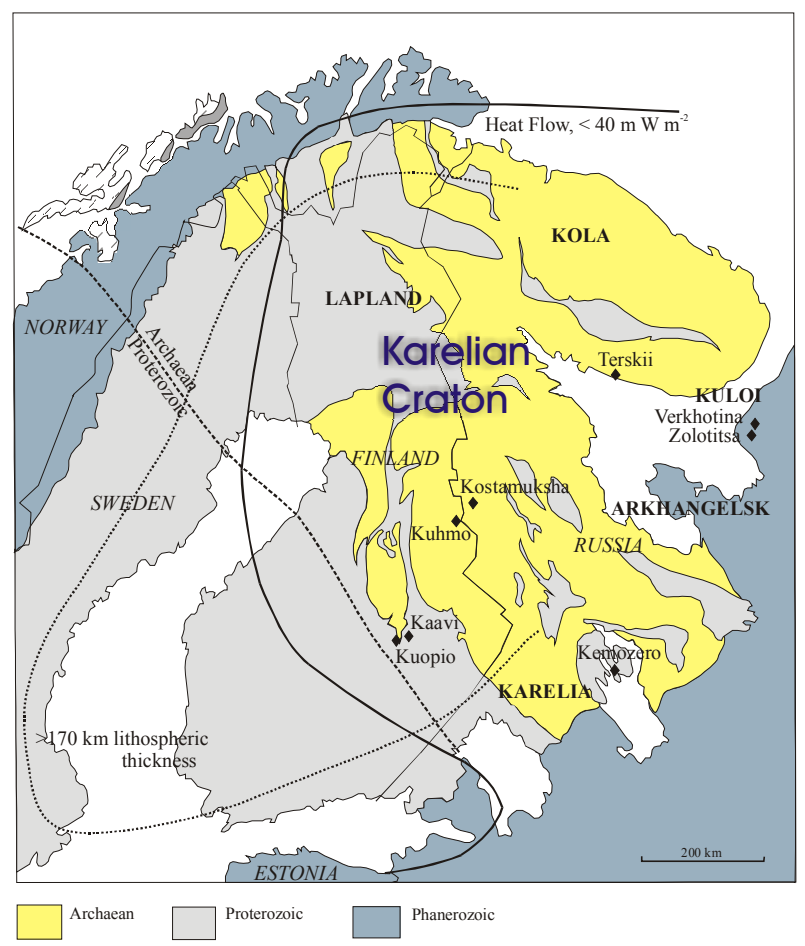

Figure 1: The map presents the diamond prospective area in Northern Europe where there is a low heat flow (simplified from Kukkonen \& Jõeleht 1996) and where the lithosphere is thicker than $170 \mathrm{~km}$ based on seismic data (Calcagnile 1982). Generalised geology is modified after Gaál and Gorbatschev (1987). The Archaean/Proterozoic boundary marks the subsurface extent of the Archaean craton. The black diamonds represent diamond-bearing kimberlites and lamproites. The $250 \mathrm{~km}$ transect considered here runs from Kaavi-Kuopio to $30 \mathrm{~km}$ north of Kuhmo.

\section{INTRODUCTION}

The Neoproterozoic Eastern Finland Kimberlite Province situated at the SW edge of the Karelian Craton consists of the Kaavi and Kuopio clusters, with nineteen kimberlites discovered, all with typical Group I mineralogies (Tyni 1997, O’Brien \& Tyni 1999). The pipes were emplaced into Archaean (3.5-2.6 Ga) basement gneisses and allocthonous Proterozoic (1.9$1.8 \mathrm{Ga}$ ) metasediments at $589-626 \mathrm{Ma}$ based on $\mathrm{U}-\mathrm{Pb}$ ion probe ages from perovskites (O'Brien $\mathrm{H}$., unpublished). Mantle xenoliths from the Kaavi-Kuopio pipes have been studied in detail by Peltonen et al. (1999) and a geotherm on the order of $36 \mathrm{~mW} / \mathrm{m}^{2}$ has 
been calculated using xenolith P-T data and heat flow constraints (Kukkonen \& Peltonen 1999).

The Mesoproterozoic transitional Group II / olivine lamproites in the Kuhmo-Suomussalmi terrain of eastern Finland show many similarities in terms of composition, mineralogy and isotopic composition (Fig. 1) to the diamondiferous rocks of the Lomonosov deposit in the Archangelsk area. However the Kuhmo versions appear to be considerably older, ca. $1250 \mathrm{Ma}$ (perovskite U-Pb, O'Brien, unpubl. data) vs. $365 \mathrm{Ma}$ (Beard et al. 1998).

\section{SAMPLES}

Xenocryst samples from the Kaavi-Kuopio field came from 4 kimberlites: 2 ha Lahtojoki (Pipe no. 7 with 26 cpht of $+0.8 \mathrm{~mm}$ diamonds), 2 ha Kylmälahti (no. 17 , marginally diamondiferous), 700 m x 30 m Kärenpää (no. 5, v. low diamond grades) and $300 \times 50 \mathrm{~m}$ Niilonsuo (no. 2, microdiamond-rich). Xenoliths, including those included in Peltonen et al. (1999) and new data presented in Lehtonen et al (this volume) came from these same pipes plus additional material from $110 \times 50 \mathrm{~m}$ Kaatronlampi (no. 24, nondiamondiferous).

At this stage in the exploration program in the target area of Lentiira, within the Kuhmo terrain, nearly all of the available data come from heavy mineral concentrates taken from till samples. Indicator fans have led to hard-rock kimberlite discoveries but the xenocrysts and xenoliths from these recent discoveries are only now being analyzed in a similar fashion to the till-derived mantle grains.

\section{ANALYTICAL TECHNIQUES}

Mineral compositions were determined by a Cameca Camebax SX50 electron microprobe at GTK. An acceleration voltage of $25 \mathrm{kV}$, probe current of $48 \mathrm{nA}$, and beam diameter of 1 micrometer were applied. Selected garnet xenocrysts were analysed for trace elements at the University of Cape Town using a Perkin Elmer / Sciex Elan 6000 inductively coupled plasma spectrometer connected to a Cetac LSX-200 laser ablation module. Data was calibrated against an inhouse standard. Trace $\mathrm{Ni}, \mathrm{Mn}$ and $\mathrm{Ti}$ data by electron microprobe were obtained on pyropes employing 500 $\mathrm{nA}$ probe current, 600s counting times on peak plus background positions and were reduced by the CSIRO TRACE program for the SX50 (Robinson \& Graham, 1992). Cross-checking of the two trace methods shows that $\mathrm{Ni}$, Ti and $\mathrm{Mn}$ analyses in pyrope by electron probe can achieve similar precision to those of LA ICP-MS down to the level of ca. $10 \mathrm{ppm}$.

The garnets were classified into harzburgitic, lherzolitic and non-peridotitic varieties according to Gurney (1984); the compositional field for wehrlitic garnet was separated from the lherzolite field using the division of Sobolev et al. (1973). Equilibration pressures and temperatures of the chrome diopside xenocrysts were calculated using the clinopyroxene thermobarometer of Nimis \& Taylor (2000, NT hereafter). Xenolith P-T data were calculated using NT and the method of Brey et al., 1990. For garnet xenocrysts the Ni thermometer based on the partitioning of $\mathrm{Ni}$ between garnet and olivine was applied using the method of Griffin et al. (1989) as recalibrated by Ryan et al. (1996).

\section{RESULTS}

\section{GEOTHERM}

Single-grain chrome diopside thermobarometry fits reasonably well with a geotherm of $36 \mathrm{~mW} / \mathrm{m}^{2}$ calculated using heat flow constraints and xenolith P-T data from Finland (Kukkonen \& Peltonen 1999). Fig. 2 in Lehtonen et al. (this volume) shows the correspondence between the xenolith and xenocryst data. Preliminary P-T data from Kuhmo chrome diopsides using the NT calibration indicate a similar geotherm, although the present sparse dataset is limited to low temperatures.

\section{MANTLE Compositions}

Pyrope trace $\mathrm{Ni}$ data were used to calculate temperatures of equilibration using both the calibration of Ryan et al. (1996; Fig. 2) and that of Canil (1999, not shown but see Lehtonen et al., this volume). The KaaviKuopio data show a bimodal distribution that includes a strong low temperature, low Ti-Zr-Y 'wehrlitic' peak at 650 to $800{ }^{\circ} \mathrm{C}$ and a stronger sampling peak at 1000 to $1150{ }^{\circ} \mathrm{C}$, which includes all but one of the $\mathrm{G} 10$ pyropes analyzed for $\mathrm{Ni}$ and a second population of more typical wehrlitic grains with elevated $\mathrm{Ti}, \mathrm{Zr}$, and $\mathrm{Y}$. At temperatures above $1150{ }^{\circ} \mathrm{C}$ exists a meltmetasomatized section of coarse granular peridotite that may represent a refertilized version of layer 2 .

In the Kuhmo terrain the sampling of mantle seems to have been rather uniform from the highest temperatures at about $1400{ }^{\circ} \mathrm{C}$ to the lowest temperatures around 850 ${ }^{\circ} \mathrm{C}$. Also relatively uniform is the distribution of $\mathrm{G} 10$ 


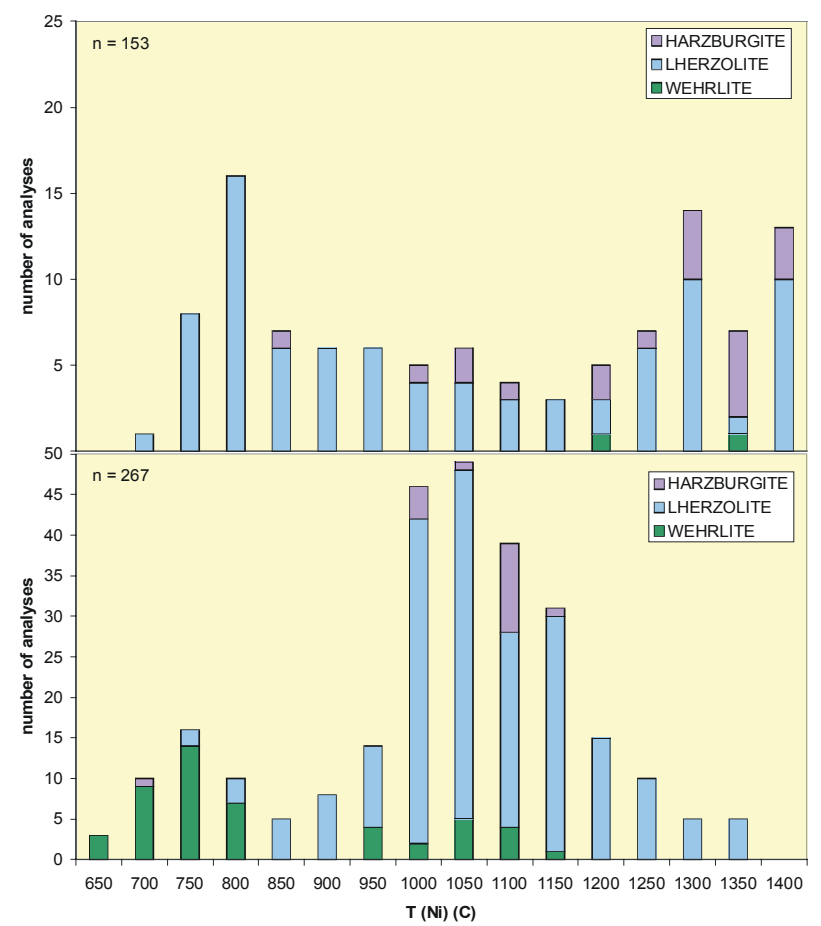

Figure 2: Distribution of TNi for trace element analyzed pyropes from this study, Kuhmo terrain (top) and KaaviKuopio (bottom).

grains (Fig. 2) throughout this section, although there is an obvious concentration of G10s near the base of the unmodified lithosphere from 1250 to $1400{ }^{\circ} \mathrm{C}$ and an absence of these grain at temperatures $<850{ }^{\circ} \mathrm{C}$. In both provinces the highest temperature at which G10 exists also represents the highest temperature at which low $\mathrm{Zr}$ and $\mathrm{Y}$ contents pyropes occur. At least at Kaavi-Kuopio this break does not however demarcate the base of the lithospheric mantle because all xenoliths collected are coarse granular peridotites, even those with equilibration temperatures significantly above $1150{ }^{\circ} \mathrm{C}$.

The two breaks in mantle stratigraphy underlying Kaavi-Kuopio also show up well using Ti contents (Fig. 3) and mg\# (Fig. 4) of pyropes, where the TNi have been projected onto the local geotherm (Kukkonen and Peltonen, 1999) to give pressures for each grain. The boundary at about $110 \mathrm{~km}$ separates extremely low $\mathrm{TiO}_{2}$ content pyropes with 'wehrlitic' compositions and mg\# around 0.80, from a more typical zone with G10 and G9 grains exhibiting a wide range in both parameters. Below the second boundary at roughly 180 $\mathrm{km}$, pyrope $\mathrm{TiO}_{2}$ contents and $\mathrm{mg} \#$ are less variable.

In the Kuhmo terrain, variable pyrope $\mathrm{TiO}_{2}$ contents are the rule, although a general increase with depth seems to be a real trend (Fig. 3). More clear is the strong $\mathrm{mg \#}$

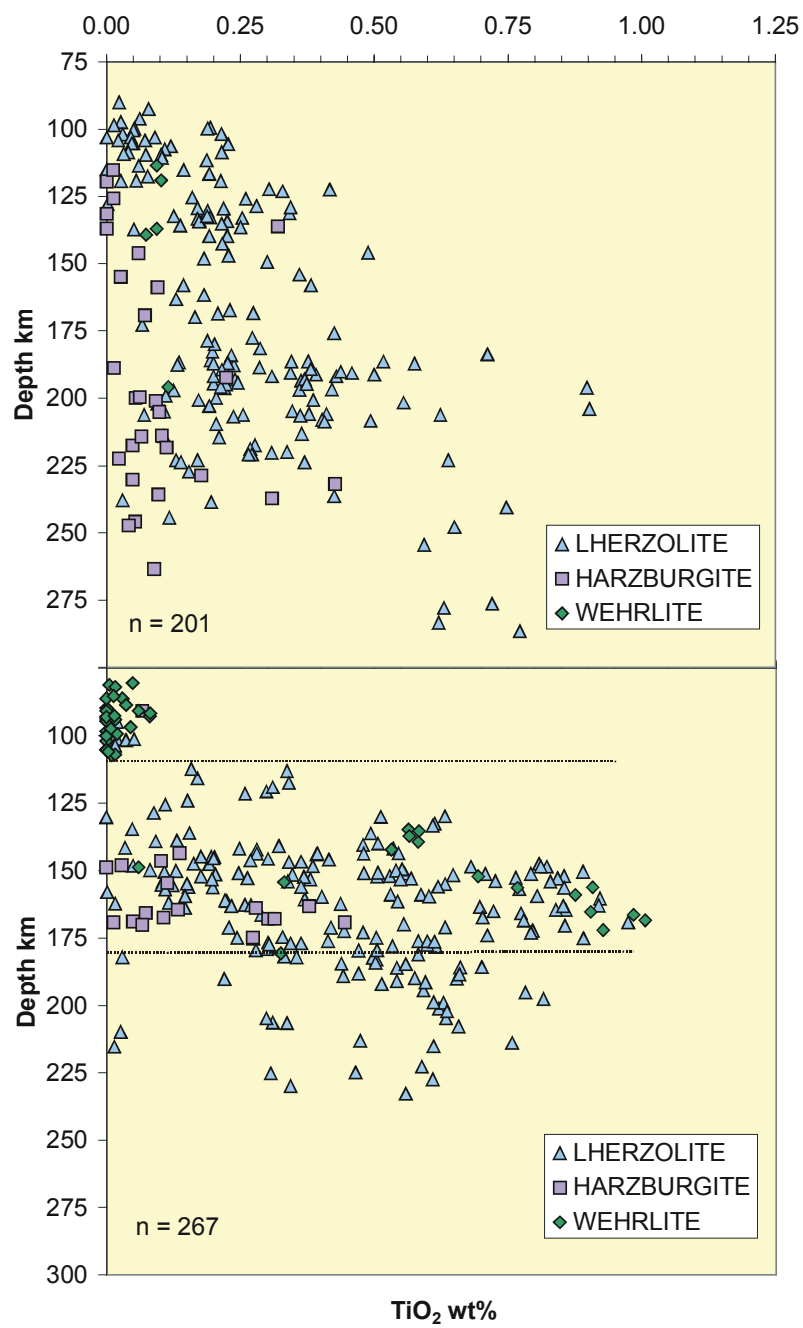

Figure 3: Calculated depth versus $\mathrm{TiO}_{2}$ content of pyropes from Kuhmo (top) and Kaavi-Kuopio (bottom).

versus depth correlation (fig 4). Although some of this correlation might be due temperature effects on gt/ol $\mathrm{Fe} / \mathrm{Mg} \mathrm{K} \mathrm{K}_{\mathrm{D}}$, a more likely mechanism by which this relationship could have been produced is an increase in the degree of partial melting with depth. In either case, we believe that this relationship must represent a primary feature of the Karelian craton from when the crust was first stabilized ca. $3.5 \mathrm{Ga}$ and this highly refractory lithospheric mantle was originally formed.

\section{SUMMARY}

A schematic correlation diagram for the two mantle sections discussed here is shown in figure 5. The lithospheric mantle at Kaavi-Kuopio consists of three layers: 1. An upper layer distinguished by extremely low Ti-Zr-Y 'wehrlitic' pyropes that occur in modally metasomatized harzburgites, 2. A middle lherzolite to harzburgite layer (with minor werhlite) representing the 
unit most sampled by the kimberlites and the most prospective for diamonds, 3. A lower melt metasomatized layer with a minor amount of remnant depleted material suggesting a previous history as a deeper extension of layer 2 . The Kuhmo terrain mantle is simpler, with $150 \mathrm{~km}$ of mixed harzburgite lherzolite, $110 \mathrm{~km}$ of it within the diamond stability field and a roughly $30 \mathrm{~km}$ thick melt-modified lower layer. An undisturbed pyrope mg\# - depth profile likely represents an original depletion event linked with the formation and ultimately the preservation of the buoyant depleted mantle underlying what may represent one of the original nuclei of the Karelian craton.
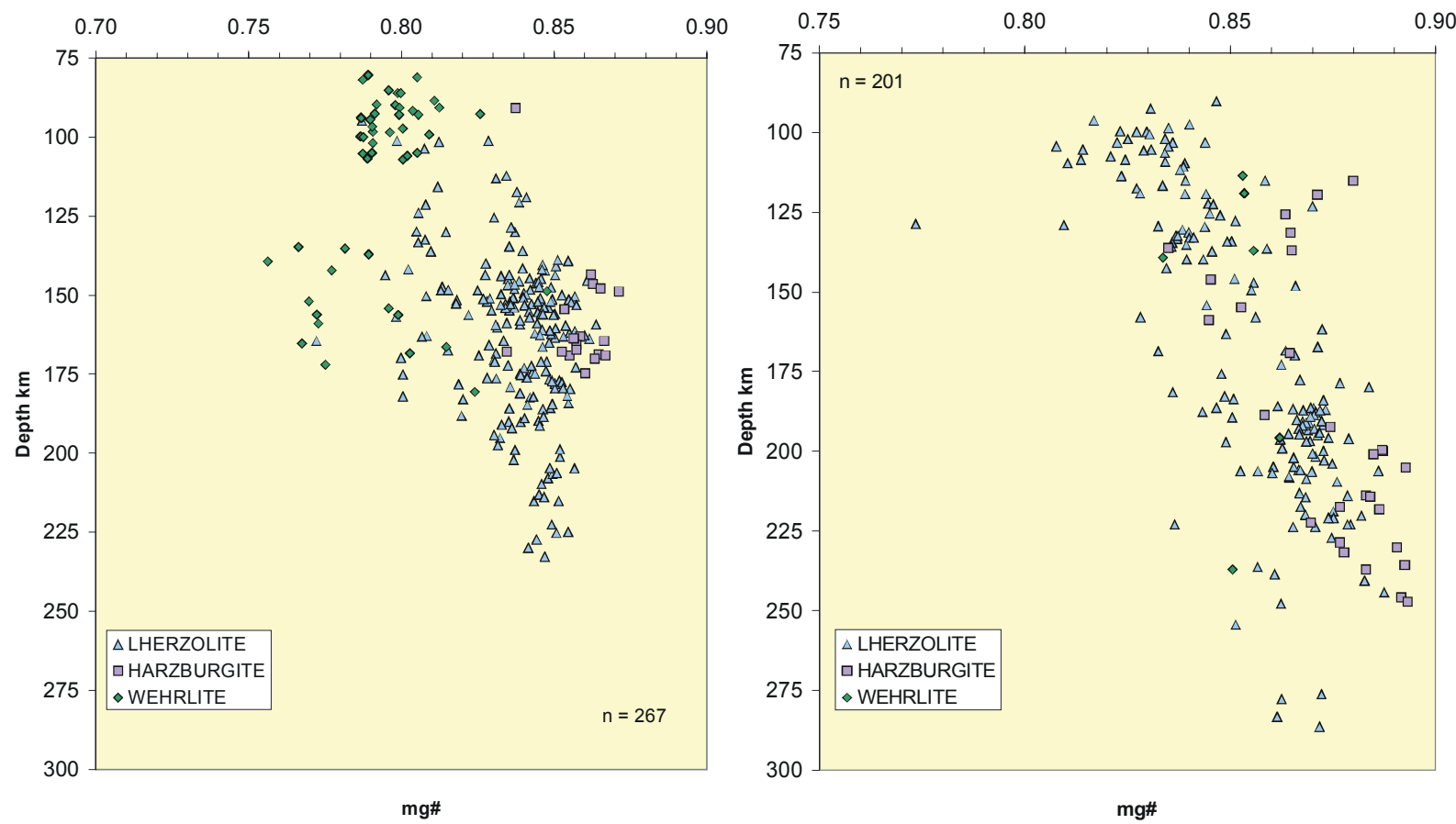

Figure 4:. Calculated depth versus mg\# for pyropes from Kaavi-Kuopio (left) and the Kuhmo terrain (right).

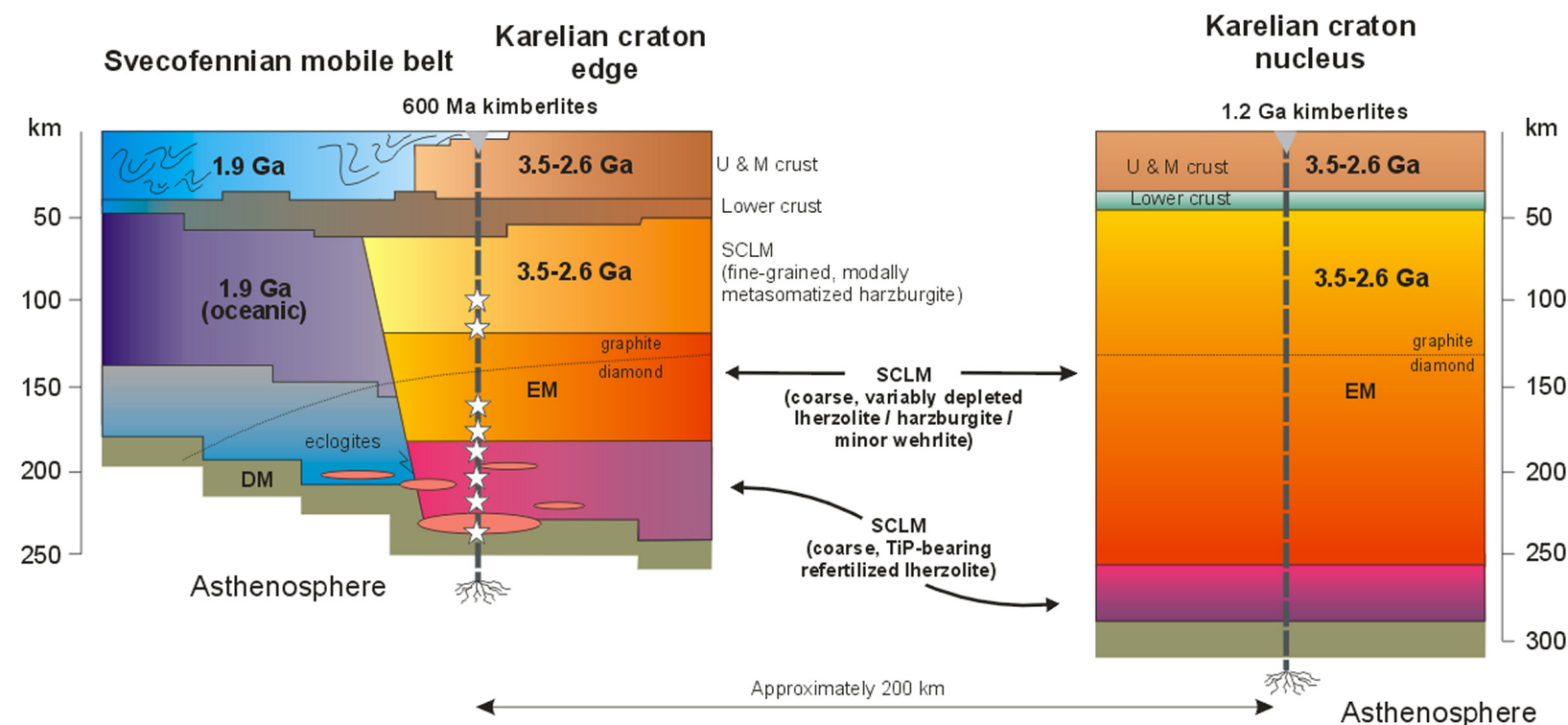

Figure 5: Schematic cross-section through the rifted and redocked edge of the Karelian craton showing the three distinct mantle layers at Kaavi-Kuopio (left) and the more simple structure inferred for the Kuhmo terrain mantle (right). Graphite - diamond stability curve from Kennedy \& Kennedy, 1976. 


\section{REFERENCES}

Beard, A.D., Downes, H., Hegner, E., Sablukov, S.M., Vetrin, V.R. and Balogh, K. 1998. Mineralogy and geochemistry of Devonian ultramafic minor intrusions of the southern Kola Peninsula, Russia:implications for the petrogenesis of kimberlites and melilitites. Contrib. Min. Petrol. 130, 288-303.

Brey, G.P., Köhler, T \& Nickel, K.G. 1990. Geothermobarometery in four-phase lherzolites I. Experimental results from 10 to $60 \mathrm{~kb}$. J. Petrol. 31, 1313-1378.

Calcagnile, G., 1982. The lithosphere-asthenosphere system in Fennoscandia. Tectonoph. 90, 19-35.

Canil, D. 1999. The Ni-in-garnet geothermometer: calibration at natural abundances. Contrib. Min. Petrol. 136, 240246.

Gaál, G. \& Gorbatschev, R., 1987. An outline of the Precambrian evolution of the Baltic Shield. Precambrian Res. 35, 15-52.

Kukkonen I.T. and Jõeleht A., 1996. Geothermal modelling of the lithosphere in the central Baltic Shield and its southern slope. Tectonophysics 255, 24-45.

Griffin, W.L., Cousens, D.R., Ryan, C.G., Sie, S.H. \& Suter, G.F., 1989. Ni in chrome pyrope garnets: A new geothermometer. Contrib. Mineral. Petrol. 103, 199202.

Gurney, J.J., 1984. A correlation between garnets and diamonds. In: Glover J.E. and Harris P.G. (eds.), Kimberlite Occurrence and Origin: A basis for conceptual models in exploration. Geol. Dept. and Univ. Ext., Univ. of WA, Publ. 8, pp. 143-166.

Kennedy, C.S. \& Kennedy, G.C., 1976. The equilibrium boundary between graphite and diamond. J. Gephys. Res. 81, 2467-2470.

Kukkonen I.T. and Jõeleht A., 1996. Geothermal modelling of the lithosphere in the central Baltic Shield and its southern slope. Tectonophysics 255, 24-45.

Kukkonen, I.T. \& Peltonen, P., 1999. Xenolith controlled geotherm for the central Fennoscandian Shield: Implications for lithosphere-astenosphere relations. Tectonoph. 304 (4), 301-315.

Lehtonen, M.L., O’Brien, H.E., Peltonen, P., Johanson, B.S. \& Pakkanen, L.K., 2003. Layered mantle at the edge of the Karelian Craton; P-T of mantle xenocrysts and xenoliths from eastern Finland kimberlites. This volume.

Nimis, P. \& Taylor, W.R., 2000. Single clinopyroxene thermobarometry for garnet peridotites. Part I. Calibration and testing of a Cr-in-cpx barometer and an enstatite-in-Cpx thermometer. Contrib. Min. Petrol. $139,541-554$.

O’Brien, H.E. \& Tyni, M., 1999. Mineralogy and geochemistry of kimberlites and related rocks from Finland. In: Gurney, J.J., Gurney, J.L., Pascoe, M.D. and Richardson, S.H. (Eds.), Proceedings of the 7th International Kimberlite Conference, pp. 625-636.

Peltonen, P., Huhma, H., Tyni, M. \& Shimizu, N., 1999. Garnet peridotite xenoliths from kimberlites of Finland: Nature of the continental mantle at an Archaean craton - Proterozoic mobile belt transition. In: Gurney, J.J., Gurney, J.L., Pascoe, M.D. and Richardson, S.H. (Eds.), Proceedings of the 7th International Kimberlite Conference, pp. 664-675.

Pollack, H.N. \& Chapman, D.S., 1977. On the regional variations of heat flow, geotherms and lithosphere thickness. Tectonoph. 38, 279-279.

Robinson, B.W. \& Graham, J. 1992. Advances in Electron Microprobe Trace Element Analysis. J. ComputerAssisted Microsopy 4, 263-265.

Ryan, C.G., Griffin, W.L. \& Pearson, N.J., 1996. Garnet geotherms: Pressure-temperature data from Cr-pyrope garnet xenocrysts in volcanic rocks. J. Geophys. Res. $101,5611-5625$.

Sobolev, N.V., Lavrentìev, Yu.G., Pokhilenko, N.P. \& Usova, N.P., 1973. Chrome-rich garnets from the kimberlites of Yakutia and their paragenesis. Contrib. Mineral. Petrol. 40, 39-52.

Tyni, M., 1997. Diamond prospecting in Finland - a review. In: Papunen H. (edit.), Mineral Deposits: Research and Exploration, Where do They Meet? Proceedings of the $4^{\text {th }}$ SGA Meeting, pp.789-791.

Contact: HE O’Brien, PO Box 96, FIN-02151 Espoo, Finland, E-mail: hugh.obrien@gsf.fi 